\title{
Bridging the gap between alternative dispute resolution and robust adverse costs orders
}

MASOOD AHMED*

Lecturer in Law, School of Law, University of Leicester

\section{Introduction}

ne of the defining features of the Woolf reforms was its attempt to shift the focus in civil litigation away from the traditional adversarial culture of resolving disputes to one which was centred on a philosophy of party cooperation and, more significantly, on settlement. As Lord Woolf made clear in his 1996 Final Report, 'the philosophy of litigation should be primarily to encourage early settlement of disputes'. ${ }^{1}$ This philosophy transformed the orthodox understanding of the civil litigation process from one that did not require the parties, in any formal sense, to engage in settlement negotiations, to one that embraced settlement as a fundamental and necessary aspect of the civil justice system.

To facilitate settlement, Lord Woolf gave alternative dispute resolution (ADR) an enhanced role within the framework of the Civil Procedure Rules (CPR). The CPR impose a positive duty upon the court to encourage parties to engage in ADR processes as part of its case management powers, and thereby act as a means to further the overriding objective of dealing with cases justly and at proportionate cost. ${ }^{2}$ The CPR also oblige parties to consider and engage in ADR processes both before and during the litigation process. ${ }^{3}$ However, Lord Woolf went further than this in his efforts to realise a change in litigation culture. He ensured that the courts were equipped with appropriate powers to penalise parties which failed to consider ADR or unreasonably refused to engage with it. ${ }^{4}$ These

* The author is grateful to John Sorabji, Andrew Higgins, Sue Prince and the anonymous reviewer for providing helpful and interesting comments on earlier drafts of this article. The author is particularly grateful to John Sorabji for guiding the author to a number of important sources of information. The usual disclaimer applies.

1 The Rt Hon Lord Woolf, Access to Justice Interim Report (Lord Chancellor's Department 1995) ch 2, para 7(a) (Interim Report) and the Rt Hon Lord Woolf, Access to Justice Final Report (Lord Chancellor's Department 1996) (Final Report).

2 CPR $1.4(2)(e)$ provides that the case management duties of the court include: 'encouraging the parties to use an alternative dispute resolution procedure if the court considers that appropriate and facilitating the use of such procedure'.

3 Before proceedings are issued the parties will be obliged to engage with the pre-action protocols. For a list of the current pre-action protocols see <www.justice.gov.uk/courts/procedure-rules/civil/rules> accessed 7 January 2015.

4 For a discussion of the various methods by which the courts may encourage ADR, see Shirley Shipman, 'Court Approaches to ADR in the Civil Justice System' (2006) 15 Civil Justice Quarterly 181. 
powers include the making of adverse costs orders against a party which, although successful in their claim or defence, is found to have unreasonably refused to engage in ADR (the 'successful party'). The consequence of such an order being made against a successful party is that the usual costs order, ${ }^{5}$ which requires the unsuccessful party to pay the costs of the successful party, is set aside. Where this occurs, the type of adverse costs order that the courts tend to make is one that restricts the successful party to or deprives it of recovering no more than some or all of its costs from the unsuccessful party. The author refers to these types of costs orders as 'cost deprivation orders' (CDOs).

However, despite the CPR conferring upon the courts the discretion to make a wide range of adverse costs orders, judges, most notably the senior judiciary, have been reluctant to fully utilise those powers. The courts appear to be more comfortable in making CDOs rather than making orders that oblige the successful party to reimburse some of the unsuccessful party's costs which that party has incurred because of the failure of the successful party to engage in ADR. The author refers to these types of costs orders as 'paying orders' (POs) because they oblige the successful party to actually make a financial contribution towards the costs of the unsuccessful party.

This article investigates and seeks to shed light upon an area which has not received attention in the current literature: the discrepancy which exists between judicial endorsement of ADR and the failure of the courts to translate or reflect that endorsement through making robust costs orders in the form of POs. It will be argued that this discrepancy has occurred as a consequence of the orthodox yet contradictory understanding among the senior judiciary that ADR, in particular mediation, is not mandatory within the English civil justice system. In this regard the author will seek to provide an alternative perspective of the Court of Appeal's decision in Halsey v Milton Keynes General NHS Trust ${ }^{6}$ by considering the effect it has had on the specific issue of the types of adverse costs orders which the courts make and the impact the decision has had upon subsequent judicial reluctance in making POs.

It will be argued that the courts should be more willing to make POs to fulfil two policy objectives. The first is to achieve fairness by reimbursing the unsuccessful party for costs it has had to incur which could have been avoided but for the successful party's failure to engage in $\mathrm{ADR}^{7}$ or, at the very least, for failing to engage in ADR which would have had the benefit of narrowing the issues between the parties and allowed the parties to gain a better understanding of the strengths and weaknesses of their arguments in the event that the parties have to revert to the court process. The second objective is to reinforce the policy of requiring parties to seriously consider ADR and, as envisaged by Lord Woolf, preserve the court process as a last resort. ${ }^{8}$

Part 1 of the article will consider Lord Woolf's ADR philosophy within the civil justice system. It will also reflect on the views of the two opposing ADR schools of thought as well as adopting a comparative approach by considering the Scottish approach towards ADR following Lord Gill's reforms to the Scottish civil courts. ${ }^{9}$ Part 2 will explain and analyse the main costs provisions under the CPR and will focus upon the court's powers to

5 CPR 44.2(2)(a).

6 [2004] 1 WLR 3002.

7 Leicester Circuits Ltd v Coates Brothers plc [2003] EWCA Civ 333; 2003 WL 1610252. Also see the comments of Lord Justice Jackson, Review of Civil Litigation Costs Final Report (14 January 2010) (Final Report) ch 36, 355-6.

8 Interim Report (n 1) s 1, para 9(a).

9 Report of the Scottish Civil Courts Review <www.scotcourts.gov.uk/about-the-scottish-court-service/thescottish-civil-courts-reform> accessed 7 January 2015. 
make adverse costs orders in circumstances where the successful party has unreasonably refused to engage in ADR. Part 3 will critically analyse English ADR jurisprudence and Part 4 will advance two alternative approaches to the making of robust adverse costs orders in cirumstances where the successful party has unreasonably refused to engage in ADR.

\section{The Woolfian ADR philosophy and diverging ADR opinions}

The role of ADR within the civil justice system was greatly enhanced as a consequence of the Woolf reforms. One of the principal aims of Lord Woolf's review of the civil justice system was to improve access to justice and reduce the costs of litigation. ${ }^{10}$ One of the main causes of these problems was, Lord Woolf observed, the traditional adversarial system of party control and minimum judicial intervention which caused or at the very least permitted the development of excessive delay in the resolution of disputes, increased costs for the parties and drained the courts' finite resources. ${ }^{11}$ Although some, like Sir Jack Jacob, the doyen of English civil procedure, favoured the adversarial system as enhancing the standing, influence and authority of the judiciary at all levels, ${ }^{12}$ Lord Woolf wanted to give effect to an idea that in pre-trial matters the court should take charge and manage disputes through the litigation process in order to ensure that litigation is conducted with reasonable speed and is pursed through mechanisms other than the court process. ${ }^{13}$ To address these ailments of the civil process, Lord Woolf sought to eliminate an adversarial approach to the conduct of litigation which allowed parties to freely engage in tactical skirmishing which increased costs and delay and undermined the court's ability to secure substantive justice (or justice on the merits). Further, Lord Woolf wanted the court to promote settlement by exercising its case management powers and thereby reduce costs and delay for the parties, even though that would not lead to a trial or produce a judgment. ${ }^{14}$ Thus, Lord Woolf believed that a trial must be avoided wherever possible and must be a last resort and one that would only be necessary if other settlement options had failed. ${ }^{15}$

More recently, Briggs LJ in his recent Chancery Modernisation Review ${ }^{16}$ has gone further in advocating the need for the Chancery courts to move away from the perception that the function of case management is almost entirely to be concerned with the preparation and management of pending proceedings to trial. Rather, courts should manage disputes in the widest possible sense in which 'a trial is statistically unlikely to be its conclusion'. ${ }^{17}$ In doing so, the courts should, Briggs LJ has recommended, take a more active role in the encouragement, facilitation and management of dispute resolution in the widest sense, including ADR as part of that process, rather than merely focusing on case preparation for trial.

The central premise upon which civil justice rests is the overriding objective of dealing with cases justly and at proportionate cost. ${ }^{18}$ The court is required to further the overriding

10 Woolf, Interim and Final Reports (n 1).

11 Woolf, Interim Report (n 1) ch 4(1).

12 Sir Jack I H Jacob QC, The Hamlyn Lectures: The Fabric of English Civil Justice (Stevens 1987) 12.

13 Woolf, Final Report (n 1). See also Lord Woolf's comments in ch 19 of Christopher Campbell-Holt, Lord Woolf: The Pursuit of Justice (OUP 2008).

14 CPR 1.4 sets out the court's duty to manage cases. CPR 1.4(2)(e) provides that active care management includes 'encouraging the parties to use an alternative dispute resolution procedure if the court considers that appropriate and facilitating the use of such procedure'.

15 Final Report (n 1) para 9(a).

16 Lord Justice Briggs, Chancery Modernisation Review: Final Report (December 2013).

17 Ibid 67-8.

18 CPR 1. 
objective ${ }^{19}$ by actively managing cases, which includes encouraging parties to use an ADR procedure if appropriate. ${ }^{20}$ There are also various obligations on the parties to consider $\mathrm{ADR}$ and settlement not only during the litigation process ${ }^{21}$ but also at the pre-action stage of litigation, i.e. before formal proceedings are issued. Before proceedings can be issued, parties are required to engage with relevant pre-action protocols, each of which require the parties to cooperate with each other in the early exchange of information and to consider and engage in settlement discussions. Lord Woolf explained that the protocols were 'intended to build on and increase the benefits of early but well-informed settlements which genuinely satisfy both parties to a dispute'. ${ }^{22}$ During his review, Sir Rupert Jackson found that the desired aims of the protocols were, on the whole, being achieved. ${ }^{23}$

Academic opinion on the significance of ADR within the civil justice system has traditionally been divided. Andrews has praised mediation and its growing status within the English civil justice system. He contends that mediation 'is a pillar of civil justice' and goes so far as to suggest that 'mediation is a valuable substitute for civil proceedings, or at least a possible exit from such proceedings'. ${ }^{24}$ The increased use of mediation has, in Andrews' opinion, resulted in 'a significant reduction in litigation before the ordinary courts, especially in the High Court'. ${ }^{25}$ Others have been more critical of ADR. Genn has expressed reservations in the increased promotion and acceptance of mediation by successive governments and the courts as a cheaper and quicker alternative to the court process. In her article 'What is Civil Justice For? Reform, ADR, and Access to Justice', ${ }^{26}$ Genn, drawing on empirical data, ${ }^{27}$ counters the 'unchallenged' notion that mediation is a cheaper alternative to the court process when she states:

it is also clear that unsuccessful mediation may increase the costs for parties (estimated at between 1,500 and 2,000 pounds) and this fact raises serious questions for policies that seek to pressure parties to enter mediation unwillingly. 28

The idea that cases that are diverted from the courts and into mediation contribute to access to justice is, according to Genn, weak because mediation is specifically non-court-based and, consequently, does not provide the parties with substantive justice. Further, the nature of mediation is such that it focuses primarily on the parties (with the assistance of the mediator) in reaching a settlement. It is not, Genn argues, about substantive justice between the parties. Rather, it is simply about settlement. As Genn puts it: "The outcome of mediation, therefore, is not about just settlement it is just about settlement. ${ }^{29}$

19 By CPR 1.3 the parties are also obliged to assist the courts in furthering the overriding objective.

20 CPR 1.4(2)(e).

21 For example, CPR 26.4 allows the parties to request a stay from the court in order to attempt settlement.

22 Woolf, Final Report (n 1).

23 Jackson, Final Report (n 7) ch 35, 352-3. For a critical evaluation of the Jackson proposal on the Practice Direction - Pre-action Conduct, see Masood Ahmed, 'An Alternative Approach to Repealing the General Preaction Protocol' (2013) 32 Civil Justice Quarterly 256.

24 <www.dike.fr/IMG/pdf/Mediation_in_England_by_N_1_._H._Andrews_Cambridge_.pdf> accessed 7 January 2015.

25 Ibid.

26 Hazel Genn, 'What is Civil Justice For? Reform, ADR, and Access to Justice' (2012) 24(1) Yale Journal of Law and the Humanities 397.

27 Hazel Genn, Twisting Arms: Court Referred and Court Linked Mediation under Judicial Pressure, Ministry of Justice Research Series 1/07 (MoJ 2007).

28 Ibid.

29 Ibid (emphasis in original). 
There is some truth in the arguement that a mediation which does not produce a settlement may increase costs for the parties. Disputing parties who have incurred costs in having to engage in an ADR process which has failed to produce a settlement will incur further costs in having to revert to the court process. Or, an unsuccessful ADR may simply be perceived by the parties as a necessary box-ticking exercise which must be completed before final judicial determination. In this regard it is interesting to note the operation of s 10 of the Children and Families Act 2014. That provision makes it mandatory for any party wishing to make a family application ${ }^{30}$ to attend a family mediation, information and assessment meeting. At this meeting the parties are provided with information regarding the mediation of family applications, ways in which such matters may be resolved other than through the courts, and to assess whether the particular matter is suitable for mediation. ${ }^{31}$ The obligation on the parties to engage in a process to effectively 'assess' whether mediation is appropriate may be seen by some as unnecessarily increasing costs and causing unnecessary delays to a process which is likely to revert to the courts in any event.

Fiss, a long-standing and ardent opponent of privatised adjudication, has compared settlement with plea-bargaining in the criminal law field. Fiss argues that settlement is:

the civil analogue of plea bargaining: consent is often coerced; the bargain may be struck by someone without authority . . . Like plea bargaining, settlement is capitulation to the condition of mass society and should be neither encouraged nor praised. ${ }^{32}$

Fiss's analysis oversimplifies the nature and operation of ADR processes such as negotiation and mediation and their relationship with court adjudication. It paints a distorted picture where parties are forced to settle without any freedom of thought or right to object or walk away from the ADR process before a binding agreement is concluded. This does not fit well, for example, when one considers that sophisticated commercial parties, such as large multinational construction corporations, will often be represented by large and specialist commercial law firms who will have the skills and knowledge to engage in ADR processes and to advise their clients as to whether to continue with the process and, indeed, whether to enter into a settlement agreement. Further, negotiation and mediation are, by their very nature, consensual. The parties are at liberty to propose and enter into mediation. They are at liberty to broker an agreement but are equally free to remove themselves from the process before an agreement is concluded. A further concern with Fiss's argument is that it fails to reflect the changing norms within modern civil justice systems which incorporate ADR as an acceptable and valuable dispute resolution process which commercial parties, in particular, have agreed to incorporate within their written transactions as the preferred option to formal court adjudication. ${ }^{33}$ Finally, Genn's contention that mediation is 'just about settlement' is also an oversimplification of the mediation models which currently exist. Genn's argument fails to take account of those ADR mechanisms such as judicial mediation which are common and popular in other common law jurisdictions, such as Canada, and which can, with the assistance of a judge who takes on the role of the mediator, offer the parties a greater understanding of the

30 S 10(3) Children and Families Act 2014 defines 'relevant family application' as 'an application that (a) is made to the court in, or to initiate, family proceedings; and (b) is of a description specified in Family Procedure Rules'.

31 Children and Families Act 2014, s 10(3).

32 Owen Fiss, 'Against Settlement' (1984) Yale Law Journal 1073. See also Owen Fiss, The Law as It Could Be (New York University Press 2003).

33 See Flight Training International Inc v International Fire Training Equipment Ltd [2004] EWHC 721 (Comm); [2004] 2 All ER (Comm) 568 in which the parties had agreed to incorporate an ADR clause into their contract and which was upheld and enforced by Cresswell $\mathrm{J}$. 
merits and weaknesses of their cases rather than serving simply as a settlement forum in which the parties are forced to settle. ${ }^{34}$

ADR has not been accepted in other jurisdictions as enthusiastically as it has been accepted in England. ${ }^{35}$ In this regard it is interesting to note the comments of Lord Gill in his review of the Scottish civil courts. ${ }^{36}$ Although recognising positive elements of mediation as an effective ADR mechanism, Lord Gill adopted a more cautious approach when reflecting upon mediation's role in civil justice. For Lord Gill, the emphasis remained firmly on the need to provide access to justice through the court system. Mediation is perceived as 'supplementing an effective court system, rather than being alternative to it'. ${ }^{37}$ Lord Gill's observations and attitude towards ADR stand in stark contrast to the evolving approach that has been adopted by the judiciary and the government in England, which is to view $\mathrm{ADR}$ as occupying an increasingly significant role within the civil justice landscape. ${ }^{38}$ Agreeing with Genn's contentions that we should not be indiscriminately attempting to drive cases away from the civil courts or compelling them, unwillingly, to enter into an additional process, ${ }^{39}$ Lord Gill placed importance upon an efficient court system as providing the primary means of resolving civil disputes. 40

There is no doubt that an efficient court system is the cornerstone of all civil justice systems. The principle that the courts are required to deliver justice is an obvious but fundamental one. In a system governed by law, the court's function is to uphold the law. In the civil context this means principally providing remedies for wrongs. In doing this, the court is required to ensure that substantive justice is achieved and substantive justice is, to borrow from Bentham, concerned with the court correctly applying right law to true facts. ${ }^{41}$ However, Lord Gill's assessment of the relationship between the court process and ADR is, like Fiss's arguments, too simplistic in that it fails to take account of the evolving role and significance of $\mathrm{ADR}$ and its interrelationship with litigation. Aside from the economic advantages associated with ADR, it also has the benefit of narrowing the legal and factual issues between the parties if a settlement is not reached. The narrowing of issues is particularly effective after the parties have filed and served their statements of claim because it will provide the parties with a further opportunity to analyse the strengths and weaknesses of their respective cases with the assistance of a neutral third party (if, for example, mediation or conciliation is used) and to weigh the risks of continuing to litigate the matter to trial. This is especially true of early neutral evaluation in which the parties benefit from obtaining an assessment of the facts and legal issues by a third-party neutral which then serves as the basis of further negotiations and the likelihood of future

34 See, for example, the favourable comments of the Canadian Chief Justice Warren K Winkler, 'Some Reflections on Judicial Mediation: Reality or Fantasy?', University of Western Ontario, Faculty of Law, Distinguished Speakers Series <www.ontariocourts.ca/coa/en/ps/speeches/reflections_judicial _mediation.htm> accessed 11 March 2015.

35 See the discussion of ADR jurisprudence in Part 3 of this article.

36 Report of the Scottish Civil Courts Review <www.scotcourts.gov.uk/about-the-scottish-court-service/thescottish-civil-courts-reform> 170 accessed 7 January 2015.

37 For example, Sir Bernard Rix, 'The Interface of Mediation and Litigation' (2014) 80(1) Arbitration 21.

38 See also similar comments by Lord Neuberger, 'Equity, ADR, Arbitration and the Law: Different Dimensions of Justice', 19 May 2010, Fourth Keating Lecture, Lincoln's Inn <www.civilmediation.org/downloadsget?id=98> accessed 7 January 2015.

39 Hazel Genn, The Hamlyn Lectures 2008: Judging Civil Justice (CUP 2008).

40 Report of the Scottish Civil Courts Review <www.scotcourts.gov.uk/about-the-scottish-court-service/thescottish-civil-courts-reform accessed $>7$ January 2015.

41 Jeremy Bentham, Rationale of Judicial Evidence in J Bowring (ed), The Works of Jeremy Bentham vol 6 (Edinburgh William Tait 1843). 
settlement or it may assist the parties in avoiding unnecessary stages in the litigation process. The benefit of ADR as an 'issues-narrowing mechanism' may have a direct and relevant relationship with the court process if the matter does not settle, which is to assist the court and the parties to manage the case more effectively and efficiently. Therefore, ADR and the court process are distinctly interlinked and complement each other in the resolution of disputes. The court system must be efficient and ADR provides an important mechanism in assisting the parties and the courts to be efficient.

\section{Court assessment of costs and adverse costs orders under the CPR ${ }^{42}$}

In order to understand the relationship between the obligation on the parties to engage in $\mathrm{ADR}$ and the courts' powers to make adverse costs orders, we must appreciate some basic principles on costs.

There are two main principles that dictate which party should pay the costs of the proceedings. The first is that the costs payable by one party to another are at the discretion of the court; there is no automatic right to the recovery of costs. ${ }^{43}$ The second principle is that the unsuccessful party will usually be ordered to pay the costs of the successful party; sometimes referred to as the usual costs order. ${ }^{44}$ However, the court may decide not to make a usual costs order because, for example, the successful party's behaviour was unreasonable during the litigation process. In these circumstances, the court may decide to make an adverse costs order by restricting the amount of costs that the successful party may recover from the unsuccessful party. In deciding which adverse costs order to make, the court will have regard to a number of factors including the conduct of all the parties. ${ }^{45}$ CPR 44.2(5)(a) elaborates that the 'conduct of the parties' includes conduct before, as well as during, the proceedings, in particular the extent to which the parties complied with the pre-action protocols. CPR 44.4(3) goes on to list a number of factors that the court must consider when assessing the amount of costs that must be paid. As with CPR 44.2(5)(a), CPR 44.4(3) includes having regard to the conduct of all the parties, including the efforts made, if any, before and during the proceedings in order to try to resolve the dispute. ${ }^{46}$

The next relevant provision is CPR 44.2(6) which sets out the adverse costs orders that can be made in substitute to the usual costs order. Those orders include an order that a party pays:

(a) a proportion of another party's costs;

(b) a stated amount in respect of another party's costs;

(c) costs from or until a certain date only;

(d) costs incurred before proceedings have begun;

(e) costs relating to particular steps taken in the proceedings;

(f) costs relating only to a distinct part of the proceedings; and

(g) interest on costs from or until a certain date, including a date before judgment.

42 Although costs are also assessed and awarded when applications are made during the litigation process, the analysis here is concerned with costs orders which are awarded after proceedings are concluded because the majority of the ADR jurisprudence concerning adverse costs orders involves the courts assessing costs at the end of trial and after carrying out an assessment of the behaviour of the parties before and after the litigation process.

43 Senior Courts Act 1981, s 51 and CPR 44.3(1).

44 Also known as 'costs follow the event'.

45 CPR 44.2(4)(a).

46 CPR 44.4(3)(ii). 
The courts are given further powers under CPR 44.11(b) to make alternative costs orders where the conduct of one of the parties is found to be improper or unreasonable. If such conduct is found then, pursuant to CPR 44.11(2)(b), the court may order the party at fault or that party's legal representative to pay costs which that party or legal representative has caused any other party to incur.

CPR 44.2(6) has the effect of reflecting a court's displeasure about the conduct of the successful party. The courts' powers under CPR 44.2(6) also enable the courts to scrutinise behaviour before the parties formally engage the court process. As Lord Phillips commented, the rule 'radically changes the costs position' ${ }^{47}$ It does so because it permits the court to use liability in costs as a sanction against a party which unreasonably refuses to attempt ADR before the action begins. Furthermore, outside of the ADR sphere, the Court of Appeal in Denton v HT White Ltd ${ }^{48}$ has strongly advocated the need for courts to adopt a more robust approach in making adverse costs orders when hearing applications for relief from sanctions pursuant to CPR 3.9. ${ }^{49}$ Following Denton, it is expected that a party not in default of procedural requirements (party A) will cooperate with his counterparty (party B) who has breached his procedural obligations so that an application by party B to the courts for relief from sanctions will not be necessary. Where party A refuses to cooperate and, instead, adopts a tactical approach so as to benefit from party B's default, then party A can expect the courts to make a robust adverse costs orders against him under CPR 44.2(6). It is this approach, as will be considered later, which provides a new impetus for robust costs sanctions to be applied where the parties are required to consider ADR.

A final point to note is that the costs orders under CPR 44.2(6) (and if the party at fault is the successful party under CPR 44.11(2)(b)) relate specifically to the obligation of a successful party to pay at least some of the unsuccessful party's costs: POs. The rationale for having POs seems fair where an unsuccessful party has had to incur additional costs or time but for the successful party's failure to engage in ADR. However, as will be discussed in Part 3, the courts have been unwilling or reluctant to make POs against a successful party which has unreasonably refused ADR.

\section{ADR jurisprudence and adverse costs orders: a critical assessment}

This part will focus upon a number of significant Court of Appeal authorities, each of which concerns ADR. It will critically evaluate the relationship between judicial endorsement and reinforcement of ADR policy and reveal the extent to which this has been reflected in the types of adverse costs orders that the courts have eventually made. First we must consider those early post-Woolf authorities which were significant in not only adopting a pro-ADR stance but which also established the first jurisprudential connections between the court's role in encouraging ADR, the parties' obligations to consider and engage with ADR and the power of the courts to make adverse cost orders where the parties failed to engage with ADR.

The emergence of jurisprudence concerning the role of ADR (in particular mediation) in litigation became clearer shortly after the enactment of the CPR. These authorities

47 Lord Phillips in Halsey (n 6).

48 [2014] EWCA Civ 906.

49 CPR 3.9 (Relief from sanctions) provides: (i) On an application for relief from any sanction imposed for a failure to comply with any rule, practice direction or court order, the court will consider all the circumstances of the case, so as to enable it to deal justly with the application, including the need - (a) for litigation to be conducted efficiently and at proportionate cost; and (b) to enforce compliance with rules, practice directions and orders.' 
heralded a strong pro-ADR stance by the senior judiciary. In Dyson v Leeds City Council, 50 Ward LJ encouraged the parties to engage in ADR, which, he observed, was consistent with the overriding objective and the court's duty to manage cases. Also, in Cowl v Plymouth City Council, 51 Lord Woolf MR was of the view that the courts should make appropriate use of their 'ample powers' under the CPR to ensure that the parties try to resolve the dispute. He went on to indicate that the courts could require the parties to provide an explanation of the steps they had taken to try to settle the matter. ${ }^{52}$

The rhetoric for the need for parties to seriously consider and engage with ADR processes was taken a step further by Brooke LJ in the leading case of Dunnett $v$ Railtrack plc. ${ }^{53}$ In that case the Court of Appeal dealt with the issue of the defendant's unreasonable refusal to consider mediation. The defendant had been successful in defending an appeal by the claimant and sought its costs of the appeal, but had previously rejected an invitation by the claimant to seek a settlement through mediation. On appeal, the defendant, Railtrack, argued that it was not willing to engage in mediation as it was not willing to offer more than what it had previously offered by way of settlement. Brooke LJ did not hesitate in rejecting the defendant's arguments and refused to award its costs. He observed that the defendant had been wrong in rejecting mediation out of hand even though it did not consider that it would bring about a settlement of the matter. In Brooke LJ's opinion, this was a misunderstanding of the purpose of ADR. He emphasised the need for the courts to further the overriding objective through active case management, which included encouraging the parties to consider ADR procedures and for the parties to also further the overriding objective in this respect. In disallowing the defendant's costs, he concluded with a stern warning to lawyers who failed to consider and engage in ADR processes:

It is to be hoped that any publicity given to this part of the judgment of the court will draw the attention of lawyers to their duties to further the overriding objective in the way that is set out in CPR Pt 1 and to the possibility that, if they turn down out of hand the chance of alternative dispute resolution when suggested by the court, as happened on this occasion, they may have to face uncomfortable costs consequences. ${ }^{54}$

Brooke LJ's judgment raises a number of points. The court adopted a favourable attitude towards settlement through ADR. Brooke LJ eloquently advocated the positive elements of ADR and, in particular, the skills and benefits of mediators in resolving disputes and their unique ability to achieve outcomes that may be beyond the scope of the court and lawyers. Further, although the court did not provide specific guidelines as to the assessment of unreasonableness, it adopted a strong policy approach in promoting ADR with the real threat of punishing a party in costs for failing to not only consider ADR but, more significantly, engage in it. Brooke LJ also mentions 'turn[ing] down out of hand the chance of ADR'. ${ }^{55}$ It follows from this that regardless of whether a party considers ADR to be appropriate will be wholly irrelevant. Brooke LJ seems to indicate that if a court suggests ADR then the parties must consider ADR. Both observations are reinforced by Brooke LJ's concluding remark that is a threat of 'uncomfortable costs consequences' for parties who refuse ADR.

50 [2000] CP Rep 42, [16].

51 [2002] 1 WLR 803.

52 Ibid [3] (Lord Woolf MR).

53 [2002] EWCA Civ 303.

54 Ibid [15] (Brooke LJ).

55 Ibid [15] (Brooke LJ). 
The earlier authorities illustrate the development of a pro-ADR judicial stance; one that was reinforced by the senior judiciary's advocacy for the need to make adverse costs orders in appropriate circumstances. ${ }^{56}$ Therefore, the ground for the emerging ADR jurisprudence was fertile for subsequent decisions of the courts to further expand, develop and strengthen the link between judicial endorsement of ADR with effective and robust adverse costs orders that went beyond simply making CDOs. However, subsequent cases appeared to undermine the pro-ADR policy which consequently led to a clear discrepancy between the courts' endorsement of ADR on the one hand and on the other its failure to give proper effect to that endorsement though the making of appropriate and robust adverse costs orders. This is well illustrated by the controversial case of Halsey.

A great deal of criticism has been made in respect of the Court of Appeal's decision in Halsey. Some commentators, including members of the judiciary, ${ }^{57}$ have criticised Halsey because of the guidelines given by the court as to when a party that has refused mediation will be perceived as unreasonable by the courts. ${ }^{58}$ Others find Halsey unfair because it places a heavy burden on the party which contends that the other has unreasonably refused mediation to prove unreasonableness. ${ }^{59}$ In fact, Ward LJ, who presided over the Court of Appeal in Halsey, recently recanted the court's decision when he said that it was time to review the Halsey principles that to oblige unwilling parties to refer their dispute to mediation would impose an unacceptable obstruction on their right of access to the courts. ${ }^{60}$ The discussion here will focus on two interrelated issues. First, it will focus upon the Court of Appeal's contradictory understanding that the courts cannot compel parties to engage in mediation; that it breaches Article 6 of the European Convention on Human Rights (ECHR) which provides the right to a fair and public hearing. This, it is argued, places unnecessary obstacles in the development of ADR jurisprudence and illustrates reluctance on behalf of the courts to match their encouragement of ADR with robust cost orders. The second issue specifically relates to the court's approach to adverse costs orders.

Halsey concerned two personal injury cases that were heard together in the Court of Appeal. The critical issue was whether the defendants should be penalised in costs for refusing mediation. In both cases the claimants and the court had recommended mediation. The trial judges refused to take into account the defendants' refusal to mediate when assessing costs. The Court of Appeal upheld the decisions at first instance and held that the defendants should not be deprived of any of their costs on the ground that they had refused to accept the claimants' invitations to agree to mediation. ${ }^{61}$

Giving the judgment of the court, Dyson LJ explained in detail the duty of the courts under the CPR to encourage the parties to engage in ADR, the types of court-based mediation schemes which are available and recognised the virtues of mediation in relevant court guides. ${ }^{62}$ However, on the question of whether the court has the power to order parties to submit their disputes to mediation against their will, Dyson LJ held that

56 For example, Hurst v Leeming [2001] EWHC 1051 (Ch); Dyson v Leeds City Council [2000] CP Rep 42; Dunnett v Railtrack (n 53); McCook v Lobo and Others [2002] EWCA Civ 1760; Leicester Circuits (n 7).

57 For example, Sir Gavin Lightman, 'Mediation: An Approximation to Justice' (2007) 73 Arbitration 400; Sir Anthony Colman, 'Mediation and ADR: A Judicial Perspective' (2007) 73 Arbitration 403; and more recently Rix (n 37).

58 For a discussion of the Halsey guidelines, see Shirley Shipman, 'Court Approaches to ADR in the Civil Justice System' (2006) 25 Civil Justice Quarterly 181.

59 Lightman (n 57).

60 Wight v Michael Wright (Supplies Ltd) [2013] EWCA Civ 498.

61 Halsey (n 6) [50] (Dyson LJ).

62 For example, the Chancery Guide and the Admiralty and Commercial Court Guide. 
for a court to require unwilling parties to mediate would breach Article 6 of the ECHR. His Lordship stated:

It is one thing to encourage the parties to agree to mediation, even to encourage them in the strongest terms. It is another to order them to do so. It seems to us that to oblige truly unwilling parties to refer their disputes to mediation would be to impose an unacceptable obstruction on their right of access to the court. ${ }^{63}$

Dyson LJ also held that, for a court to exercise its discretion on costs and impose an adverse costs order against a successful party, the burden is upon the party seeking the imposition of an adverse costs order to establish that the successful party acted unreasonably. The burden is not on the successful party to prove that its refusal to mediate was reasonable. ${ }^{64}$

Dyson LJ went on to recognise that the form of encouragement by the courts may be 'robust'. The strongest form of encouragement would take the form of an ADR order made in the Admiralty and Commercial Court. ${ }^{65}$ Any party that fails to take part in ADR after a court order has been made or refuses to consider whether ADR is suitable will, Dyson LJ warned, be at risk of having an adverse costs order being made against it.

A number of observations can be made in respect of Dyson LJ's judgment. First, his Lordship makes brief reference to the earlier ADR cases of Cowl and Dunnett but fails to recognise that both authorities strongly favoured ADR and advocated the obligations of the parties to engage in ADR processes. A further difficulty with the court's judgment in Halsey relates to the notion that the courts cannot compel the parties to engage in ADR. The failure to recognise that this power exists, albeit impliedly through the threat of adverse costs orders, places a further obstacle in the way of ADR and the full realisation by the court of its powers to penalise a party through a range of costs orders including by way of POs. Dyson LJ fails to reconcile his opinion (although obiter dicta) that a court cannot compel mediation with Blackburn J's comments in Shirayam Shokusan Company Ltd v Danovo $L t d^{66}$ and the approach taken by Arden J in Guinle $v$ Kirreh, Kinstreet Ltd ${ }^{67}$ in which the court made an ADR order despite one of the parties being unwilling to take part in ADR. Also, in Phillip Garritt-Critchley, 68 the district judge made an Ungley Order which required the parties not only to engage in mediation but also to provide witness statements to explain why a party refused to attend mediation. This act in ordering mediation and requiring sealed witness statements to be provided to the court is clear evidence of the courts' willingess to compel parties to engage in mediation regardless of the parties' opinions. Clearly, the Court of Appeal is not bound by the decision of the lower courts, however, Dyson LJ failed to consider two cases that dealt directly with one of the central issues in Halsey - can the courts compel unwilling parties to mediate? Despite Dyson LJ's obiter comments, Shirayama and Guinle, both High Court authorities, remain the law, albeit not followed in practice.

There also appears to be a paradox within Dyson LJ's reasoning as to the issue of encouragement of ADR by the courts. He purports to support his argument that the courts may encourage ADR in the form of, for example, an ADR order in the Commercial Court or an Ungley Order. If Dyson LJ contends that parties cannot be compelled to mediate, then his notion of court encouragement of ADR is contradictory. When one considers the wording of both the above orders it is clear that there exists an element of compulsion. The

63 Halsey (n 6) [9] (Dyson LJ).

64 Ibid [13] (Dyson LJ).

65 In the form set out in Appendix 7 to the Admiralty and Commercial Court Guide.

66 [2003] EWHC 3306 (Ch).

67 [2000] CP Rep 62.

68 Phillip Garritt-Critchley v Ronnan [2014] EWHC 1774 (Ch). 
ADR order in the Commercial Court requires the parties to engage in ADR but also goes further and, in the event that the parties are unsuccessful in resolving their dispute through ADR, places a burden on the parties to provide reasons as to why the matter could not be settled. Therefore, it is argued that the concept of 'encouragement' of ADR by the courts is a term that is unclear and misleading in the light of the Halsey jurisprudence. What appears from Halsey is the court's desire to actively encourage ADR while at the same instance compelling parties to consider, engage and even settle their dispute with the threat of adverse costs consequences as the driving force in directing the court's approach.

Dyson LJ considered whether the court should make an adverse costs order against a successful public body on the grounds that it refused to agree to ADR. It was argued by the claimants that public bodies should be held to their ADR pledge following the High Court decision of Royal Bank of Canada v Secretary of State for Defence ${ }^{69}$ in which the court stated that the ADR pledge should be given 'great weight'. Dyson LJ, who held that the judge in Royal Bank of Canada had been wrong to attach such weight to the ADR pledge, rejected this argument. The pledge, Dyson LJ explained, was no more than an undertaking that ADR would be considered and used in all suitable cases. If the case is not suitable for ADR, then a refusal to agree to ADR does not breach the pledge. There is logic in Dyson LJ's analysis of the ADR pledge. The pledge does not have the force of law; it is not a statutory requirement for public bodies to engage in ADR. But the issue is this: Dyson LJ appears to go to the opposite extreme when arguing that the ADR pledge was not relevant. Yes, to say that it must be given 'great weight' is to also go too far. But where a party invites a public body to mediation and does so within the context of a strong pro-ADR atmosphere, then the ADR pledge should have been taken into account when assessing the 'conduct' of the parties.

One of the main criticisms of Halsey is that it was fundamentally wrong on the issue that the court could not compel the parties to engage in mediation as it breached Article 6 of the ECHR. Sir Gavin Lightman ${ }^{70}$ has convincingly argued that the court appeared to have been unfamiliar with the mediation process and to have confused an order for mediation with an order for arbitration or some other order which places a permanent stay on proceedings. An order for mediation does not interfere with the right to a trial: at most it merely imposes a short delay to afford an opportunity for settlement and indeed the order for mediation may not even do that, for the order for mediation may require or allow the parties to proceed with preparation for trial. Sir Gavin went on to state that the Court of Appeal appears to have been unaware that the practice of ordering parties to proceed to mediation regardless of their wishes was prevalent elsewhere throughout the Commonwealth, the USA and other jurisdictions. ${ }^{71}$

Further, the European Court of Justice's ruling in Alassini v Telecom Italia SpA $A^{72}$ has made clear that the Italian law in question which required customers to engage in a form of compulsory mediation before they could bring legal proceedings did not breach Article 6 . The Italian law, in the opinion of the Advocate General Kokott, pursued legitimate objectives in the general interest in the quicker and less expensive resolution of disputes. The measure of requiring parties to engage in settlement discussions before commencing court proceedings was proportionate because no less restrictive alternative existed to the implementation of a mandatory procedure since the introduction of an out-of-court settlement procedure which is merely optional is not as efficient a means of achieving those

69 [2003] EWHC 1841 (Ch).

70 Lightman (n 57).

71 For example, in Canada and Australia.

72 Alassini v Telecom Italia SpA (joined cases C-317-320/08) [2010] 3 CMLR 17 ECJ. 
objectives. The Italian law did not seek to replace court proceedings and therefore access to the court was not denied but, at worst, delayed by 30 days.

Finally, although the Court of Appeal referred to the basic costs rules and the factors the courts will consider when assessing whether to make adverse costs orders, the court failed to provide guidance or comments upon the range of adverse costs orders that are at the disposal of the court. The claimants in both cases raised the argument that the defendants should be deprived of their costs and that was the order at the heart of the appeal. However, given the significance of the case and the precedent it was to set for future cases concerning ADR and the powers of the courts to make adverse costs orders, the Court of Appeal appeared to have fallen short in providing guidance on that issue. This shortcoming in Halsey is clearly illustrated when we come to analyse Briggs LJ's judgment in PGF II SAv OMFS Company $1 \mathrm{Ltd}^{73}$

The restraining force of Halsey upon judicial discretion to make appropriate adverse costs orders can be seen in Burchell v Bullard. ${ }^{74}$ In that case Ward LJ expressed himself in the following way when commenting on the sums involved: 'A judgment of $f, 5000$ will have been procured at a cost to the parties of about $f, 185,000$. Is that not horrific?'75 This was, he said, 'par excellence the kind of dispute which, as the recorder found, lends itself to ADR'. ${ }^{76} \mathrm{He}$ also found that the defendant's refusal to mediate had been unreasonable but, because the invitation to mediate pre-dated Halsey, Ward LJ did not impose cost sanctions even though he was of the view that the 'court should mark its disapproval of the defendants' conduct by imposing some costs sanction'.

In his Final Report, Sir Rupert also took the opportunity to expressly reject the notion of compulsory mediation when he said: 'In spite of the considerable benefits which mediation brings in appropriate cases, I do not believe that parties should ever be compelled to mediate. ${ }^{77}$ But despite this explicit rejection of compulsory mediation, his Lordship provided guidance as to the steps which courts could take to 'encourage' parties to participate in mediation, which included penalising the parties in costs. However, Sir Rupert's view on compulsory mediation or compelling parties to engage in mediation and subsequent guidance on encouraging mediation seems, like Dyson LJ's judgment in Halsey, to create a paradoxical approach towards compulsory mediation. It is this paradox which, coupled with the decision in Halsey, currently exists in English civil justice. On the one hand, the courts' official approach to mediation is that it should not be made compulsory but, on the other hand, judicial and extrajudicial statements indicate that there exists a form of compulsory mediation within the English civil justice system. Indeed, Lord Woolf alluded to the possibility of revisiting the idea of compulsory mediation when discussing his Interim Report in Hong Kong. Lord Woolf noted that, although he had not gone so far as to recommend compulsory mediation in the English system, he was 'encouraged to think that that is something which I should look at again'. ${ }^{78}$

Although subsequent Court of Appeal authorities continued to uphold the general proADR policy, it is submitted that a closer examination of the facts of some of those cases indicates a lack of progress in expanding the wider range of costs orders even though the facts would justify such orders being made. This can be seen in the case of Rolf $v D e$

73 [2014] 1 WLR 1386.

74 [2005] EWCA Civ 358.

75 Ibid [23] (Ward LJ).

76 Ibid [41] (Ward LJ).

77 Jackson, Final Report (n 7), ch 36, 355-356.

78 The Rt Hon the Lord Woolf, 'A New Approach to Civil Justice', 1996, Hong Kong Lecture. 
Guerin. ${ }^{79}$ In that case the claimant had made various invitations to the defendant to enter settlement discussions and, later, mediation which the defendant rejected. On appeal, when asked by the court why he had been unwilling to mediate, the defendant stated that if he had participated in mediation then he would have had to accept 'his guilt' and that he would not have been able to demonstrate to a mediator what the claimant's husband was like, as this could only be done at trial. In any event, he wanted his 'day in court'. Rix LJ did not hesitate in dismissing these reasons and found that the defendant's refusal to mediate was unreasonable behaviour for the purposes of CPR 44(5) and, as a consequence, the court was entitled to exercise its discretion and make no order as to costs. ${ }^{80}$

Although Rix LJ acknowledged that the courts have been unwilling to compel parties to mediate, his Lordship reinforced the trend that parties will be expected to consider and engage in mediation, and a refusal to do so will be considered as unreasonable behaviour which will justify the making of an adverse costs order against the defaulting party. Any reason for refusing mediation must be strong and grounded in the facts and law for it to withstand judicial scrutiny - any reason which is slightly weak will be dismissed by the courts and will amount to legitimate 'circumstances' in making an adverse costs order.

Rix LJ appears to take the approach that has developed through the jurisprudence in the area of ADR and mediation. His judgment confirms that, although mediation may not always produce a solution or a satisfactory solution for the parties, the court will expect parties to engage in mediation as a matter of course. A further observation relates to the costs order Rix LJ made. It was an order of no costs, that is, the successful defendant was deprived of claiming his costs. Upon closer examination of the facts it could be argued that the defendant's unreasonable conduct in pursuing the matter in order to have his 'day in court' rather than accept two offers to mediate by the claimant caused the claimant to unnecessarily remain in the litigation process and to incur costs as well as the time and resources of two courts. Indeed, Rix LJ made the point that there was a reasonable prospect that the mediation would have been successful. The court also noted that the claimant had also behaved unreasonably but, the fact remains, the claimant discharged her ADR obligations as required by the CPR and ADR jurisprudence. The defendant did not and there was a possibility that the matter would have settled without the need for the parties and the courts to incur further costs: a more robust costs order was required.

Some of the failures of Halsey concerning adverse costs orders and the reluctance of the courts to exercise their powers in making POs can be seen in PGF. The claimant, at an early stage in the litigation process, wrote to the defendant requesting that it participate in mediation and, four months later, the claimant sent a second letter inviting the defendant to ADR. However, the defendant failed to respond to these invitations and instead made a Part 36 offer without providing an explanation as to the basis of that offer.

The matter eventually settled, with the claimant accepting the defendant's Part 36 offer. Although the ordinary consequence of the claimant's acceptance of the defendant's Part 36 offer was that it would have to pay the defendant's costs for the relevant period unless the court ordered otherwise, ${ }^{81}$ the claimant gave notice that it would seek an order for costs in its favour. At the costs hearing the claimant argued, inter alia, that the defendant was unreasonable to have refused to participate in ADR. The ADR point succeeded in part, in the sense that, while depriving the defendant of its costs for the relevant period, the judge did not accept the claimant's submission that it should also be paid its costs for that period.

79 [2011] CP Rep 24.

80 Ibid [41] (Rix LJ).

81 CPR 36.10(4) and (5). 
Gross LJ gave permission to the defendant to appeal and the claimant to cross-appeal the ADR point on the ground that the application of Halsey to the facts might be of potentially wide importance.

Giving the leading judgment, Briggs LJ emphasised the importance of the role and success of ADR in settling civil disputes, especially after the Jackson reforms. Briggs LJ also noted that ADR conferred cost benefits to the parties and to court resources. ${ }^{82}$ More significantly, Briggs LJ formally endorsed the advice given in the Jackson ADR Handbook 83 that silence in the face of an invitation to participate in ADR is, as a general rule, of itself unreasonable, regardless of whether an outright refusal, or a refusal to engage in the type of $\mathrm{ADR}$ requested, or to do so at the time requested, might have been justified by the identification of reasonable grounds.

The defendant also contended that the judge, having concluded that an offer of mediation had been unreasonably refused, mechanistically deprived the defendant of the whole of its entitlement against the claimant during the relevant period without weighing up all other relevant factors. The claimant, on the other hand, argued that the judge should have ordered the defendant to pay the claimant's costs in respect of the relevant period. Briggs LJ, agreeing with the defendant's arguments, observed that a finding of unreasonable conduct did not automatically result in a costs penalty. It is simply an aspect of the parties' conduct that needs to be addressed in a wider balancing exercise. It followed from Halsey and other cases that the proper response would be to disallow some or all of the successful party's costs. Briggs LJ also noted that Halsey did not recognise that the court might go further and order the otherwise successful party to pay all or part of the unsuccessful party's costs. Although Briggs LJ recognised that the court must, in principle, have this power, it would only be exercised in the most serious and flagrant failures to engage with ADR. ${ }^{84}$ Therefore, the claimant's cross appeal was also dismissed.

Briggs LJ's judgment focuses upon the circumstances where a party refuses to respond to 'repeated' invitations to engage in ADR and this creates uncertainty. A better approach would have been for the Court of Appeal to have held that silence in the face of any invitation to engage in ADR would be considered as unreasonable and would justify the defaulting party being penalised in costs. Secondly, Briggs LJ suggested that it would be highly unusual for the costs sanction to take the form of requiring the party refusing mediation (i.e. the successful party) to pay some or all of the other party's costs: 'a sanction that draconian should be reserved for only the most serious and flagrant failures to engage with ADR'. ${ }^{85}$ This approach is surely too cautious. It would be better if the court had acknowledged that an appropriate costs sanction is that a party in default of invitations to engage in ADR will be liable to pay the other's costs by way of a PO. Briggs LJ's observations that Halsey did not recognise that the unreasonable party may be ordered to pay the costs of the other party represents a missed opportunity in clarifying and reinforcing this area of law. Although Halsey did not deal with this issue, it did not prevent the Court of Appeal from exercising its powers, which Briggs LJ concedes the court would have, to make such an order on the facts of the case.

82 PGF (n 73) [24]-[30] (Briggs LJ).

83 Susan Blake, Julie Browne and Stuart Sime, The Jackson ADR Handbook. (OUP 2013).

84 PGF (n 73) [51]-[52] (Briggs LJ).

85 Ibid [52] (Briggs LJ). 


\section{An alternative approach}

This article has revealed the discrepancy that exists between judicial endorsement of ADR and the senior judiciary's reluctance to reflect that through the making of POs. The Court of Appeal's decision in Halsey undermines the evolution of adverse costs orders and continues to restrain judicial acceptance of its powers to compel parties to engage in ADR and to punish successful parties by way of POs. If the judiciary is committed to effect a change in litigation culture as envisaged by Lord Woolf, then that should be reflected through the making of appropriate robust costs orders (in circumstances which justify such orders being made) rather than simply paying lip-service to the general importance and benefits of ADR.

Judicial approaches to adverse costs orders against a successful party do not take account of the financial loss caused to the unsuccessful party. This is unfair and fails to strike an appropriate balance between the obligation of the parties to consider ADR and the need to reimburse a party that has complied with its obligation but which is now out of pocket as a result of the other party's default. This is not to say that every ADR process would have been successful and, therefore, would have saved the unsuccessful party litigation costs. However, one may reasonably argue that, had the parties engaged in ADR, then there is a strong likelihood that they would either have settled during the ADR process or at some point after it. Indeed, this is a line of argument the courts have raised in a number of significant ADR cases. In Leicester Circuits Ltd $v$ Coates Brothers plc, 86 for instance, the Court of Appeal disapproved of the defendant's decision to withdraw from a mediation that the parties had arranged and rejected its argument that it would have been pointless to participate in it. Judge LJ was strongly of the conviction that, although it could not be assumed that the mediation would have succeeded, 'there [was] a prospect that it would have done if it had been allowed to proceed'. ${ }^{87}$ More recently, Judge Waksman QC in Phillip Garritt-Critchley $v$ Ronnan ${ }^{88}$ granted an indemnity costs order against the defendants for unreasonably refusing to engage in mediation. He rejected the defendant's contention that the claim did not provide any middle ground between the parties and that the defendants were confident that an agreement could not be reached by engaging in the mediation process: 'To consider that mediation is not worth it because the sides are opposed on a binary issue, I'm afraid seems to me to be misconceived. ${ }^{89}$ It was only by sitting down and exploring settlement that the parties could really ascertain 'how far apart they really were.'90

How, then, can the gap between judicial encouragement and promotion of ADR be filled so that the courts, in appropriate cases, can utilise the full range of adverse costs orders including making a PO where a successful party has unreasonably refused to engage in ADR? It is submitted that two options may be considered to bring about a change. The first option demands the formal acknowledgment by the judiciary that it has the power to compel parties to engage in ADR: Halsey needs to be reappraised judicially and its approach rejected. The power to compel parties to engage in ADR would only be restricted to the point at which the courts order the parties to explore settlement through an appropriate ADR process; it would not, however, extend to compelling parties to actually settle their dispute through ADR. The exercise of this power would be underpinned by the obligation of the courts (and the parties) to further the overriding objective and the need for the

86 Leicester Circuits (n 7).

87 Ibid [27] (Judge LJ).

88 Phillip Garritt-Critchley (n 68)

89 Ibid [14] (Judge Waksman QC).

90 Ibid [22] (Judge Waksman QC). 
courts to provide proportionate justice. Where the first option may prove to be too radical, then a second option may be considered. It rests on the need for the courts to make better use of their existing powers on costs and be more willing to make a PO where there has been an unreasonable refusal to engage in ADR. It is submitted that this option is reinforced by the Court of Appeal's recent approach on the issue of procedural noncompliance and relief from sanctions as formulated in the Court of Appeal authorities of Mitchell $v$ News Group Newspapers Ltd ${ }^{91}$ and Denton, ${ }^{92}$ which have provided a new impetus for costs sanctions to be applied where ADR is concerned. Let us consider the two options in greater detail.

The first option is the most radical. It is radical because it demands a departure from the orthodox position in English civil procedure that ADR is not and should not be made compulsory. However, that orthodox position is untenable. Despite the formal rejection by senior members of the judiciary of the idea of court-compelled ADR, there is, as discussed in Part 3, evidence that the courts do compel parties to engage in settlement processes and that the parties run the risk of suffering by way of adverse costs orders where they have failed to engage in ADR or have unreasonably refused to engage in ADR. And this is well illustrated by the Phillip Garritt-Critchley case in which the district judge made an order in the following terms: 'the court considers the overriding objective would be served by the parties seeking to resolve the claim by mediation'. ${ }^{93}$

The courts' powers to compel parties to engage in ADR must be underpinned and guided by the overriding objective of dealing with cases justly and at proportionate cost. Although the courts have, in some cases, utilised the overriding objective in ordering that parties should consider ADR, the courts must make greater use of the overriding objective in seeking to provide the parties with proportionate justice. And the parties would also be required to assist the court in furthering the overriding objective as required under CPR 1.3. To understand and fully appreciate the concept of proportionate justice and how it relates to the first option, a more detailed analysis of the overriding objective is called for.

The overriding objective is the bedrock of the civil justice system. It underpins the CPR and guides the courts in the management of civil disputes and dispensing justice. When introduced by Lord Woolf, the overriding objective was revolutionary in transforming the concept of 'justice' from one which was primarily concerned with seeking to achieve substantive justice (or justice on the merits) between the parties to a broader concept of justice. ${ }^{94}$ The courts could no longer simply be concerned with achieving substantive justice; this now had to be balanced with other considerations. As Lord Woolf MR explained: 'The achievement of the right result needs to be balanced against the expenditure of the time and money needed to achieve that result. ${ }^{95}$ Lord Woolf MR also spoke of the need to have proportionate justice and this meant that no more than proportionate costs should be expended on individual cases - the courts had to consider the rights of other litigants to have access to justice. ${ }^{96}$ This was taken further under the Jackson reforms, which amended the Woolfian overriding objective to give express recognition to the principle of

91 [2013] EWCA Civ 1537.

92 Denton (n 48).

93 Phillip Garritt-Critchley (n 68) [6] (Judge Waksman QC).

94 The pre-Jackson overriding objective under CPR 1.1(1) stated: 'These rules are a new procedural code with the Overriding Objective of enabling the court to deal with cases justly.'

95 Woolf, Interim Report (n 1) ch 4, para. 6.

96 See Lord Woolf MR's comments in Beachley Property Ltd v Edgar [1997] PNLR 197. 
proportionality within CPR 1.1(1) ${ }^{97}$ and the obligation on the parties to comply with rules, practice directions and court orders.

Therefore, the overriding objective is concerned with the need to achieve proportionate justice as opposed to simply seeking to achieve substantive justice between the parties. The courts must consider the rights of other litigants to have access to justice. Sorabji explains that the policy aims of time and cost are intended to support the achievement of the wider public policy aim of ensuring that the limited resources allocated by the state to the justice system can be distributed fairly amongst all who rely on the state to vindicate and enforce their rights and obligations. ${ }^{98}$ Thus, Sorabji argues, the new theory of justice is concerned with securing distributive justice rather than justice on the individual merits of the case. As a consequence, litigants are provided with a system of judicial resolution of disputes that ultimately seeks to achieve proportionate justice.

Applying the overriding objective, the courts must seek to further the principle of proportionality when considering whether a particular dispute is suitable for ADR. It may be that the facts and issues of a particular case are such that justify it being resolved through mediation rather than incurring court resources in allowing the matter to be pursued through the court process. By doing this, the courts will be effectively applying and furthering the overriding objective in ensuring that the parties are provided with proportionate justice.

The second option has two elements:

1. the need for the removal of artificially high and unrealistic thresholds that restrict the making of POs and greater use by the courts of their cost powers;

2. to reinforce element 1 above, amending the costs rules to make clear that, when assessing costs, the courts will have regard to ADR as an important cost-saving mechanism for the parties and the court.

There must be a fundamental change in judicial attitudes and approaches to the making of adverse costs orders and the removal of artificially high thresholds in making POs. Although Briggs LJ in PGF suggested that the courts possessed the powers to make POs against successful parties, his Lordship immediately restricted this by setting a high threshold of 'flagrant breaches' which, if met, would justify an order being made. However, this test is vague, artificial and contradictory. It is unclear as to what is actually meant by 'serious and flagrant breaches'. The fact that the Court of Appeal did not expand on the circumstances where the test would apply (whether by way of non-exhaustive examples or by providing factors which the courts would take into account when applying the test) does not assist in the theoretical understanding of the test and its practical application. It is contradictory because, as argued, repeated invitations can reasonably be interpreted as a 'serious and flagrant breach' of the parties' duties to consider and engage in ADR and therefore would justify the making of a PO against the successful party. Further, the test does not sit well with the policy of ADR consistently advocated by the courts. If, as Dyson LJ stated in Halsey, the most robust form of encouragement would be an ADR order, then surely, where a successful party had refused ADR unreasonably after such an order had been made, that conduct in itself should justify the making of an equally robust costs order in the form of a PO. Although Dyson LJ did not, as Briggs LJ rightfully observed in PGF, discuss POs in Halsey, the court in PGF was in a position to not only formally acknowledge

97 For an interesting discussion of the concept of proportionality, see J Sorabji, 'Prospects for Proportionality: Jackson Implementation' (2013) 32(2) Civil Justice Quarterly 213.

98 John Sorabji, The Woolf and Jackson Reforms: A Critical Analysis (CUP 2014). 
that the courts have the powers to make POs, it should also have made such an order, which was justified on the facts. This would have bridged the gap that currently exists between strong judicial endorsement of ADR and the making of cost orders that reflect and reinforce that endorsement.

It may be argued by some that Briggs LJ's (overly) cautious approach is justified on the grounds that POs are too heavy handed, too draconian and, in any case, the courts are able to make CDOs which serve the purpose of penalising a successful party in costs. However, this argument unduly restricts the court's discretion and its powers to exercise the full range of adverse costs orders. The powers to make a range of adverse costs orders have been provided to the courts by the CPR and are there to be utilised and should be utilised in appropriate cases. This approach is supported by the Court of Appeal's robust stance concerning circumstances in which a party has failed to cooperate with its counterpart which has breached a process requirement and is forced to make an application for relief from sanction under CPR 3.9.

The landmark cases of Mitchell MP and News Group Newspapers 99 and Denton dealt with the issue of the approach the courts should adopt where a party has failed to comply with process requirements and then makes an application for relief from sanctions. In both cases the court advocated the need to adopt a more robust and less forgiving stance when considering applications for relief from sanctions. In particular, in Denton the court advocated the need to adopt robust judicial approaches in making adverse costs orders to penalise a party that failed to behave reasonably in agreeing to extensions of time or that unreasonably opposed applications for relief from sanctions. ${ }^{100}$ This behaviour, the court noted, ran counter to the duty of the parties to further the overriding objective. Giving a joint judgment of the court, Lord Dyson MR and Vos LJ made clear the need for the courts to make heavy costs sanctions which went beyond simply requiring the unreasonable party to pay the cost of the application when they stated:

[T] he court will be more ready in the future to penalise opportunism. The duty of care owed by a legal representative to his client takes account of the fact that litigants are required to help the court to further the overriding objective . . . Heavy costs sanctions should, therefore, be imposed on parties who behave unreasonably in refusing to agree extensions of time or unreasonably oppose applications for relief from sanctions. ${ }^{101}$

The court also held that an unreasonable party would not only be required to pay the costs of the application for relief but it may also be required to suffer further cost sanctions (by way of a $\mathrm{CDO}$ ) at the end of the proceedings even though it may be the successful party. Although the Court in Denton spoke of CDOs being made against the successful party, the principle that a more disciplinarian approach be adopted, which requires the making of 'heavy costs sanctions', is one that lends support to the argument that the courts should also adopt an equally robust approach to costs when dealing with ADR. This would include the courts making costs orders which have the aim of reimbursing the unsuccessful party for costs it has incurred because of the successful party's unreasonable behaviour in refusing to engage in ADR.

The second element of the second option requires the rules on costs to be amended so that they make clear that the court will have regard to factors which could have saved the parties and the court costs when considering whether to make adverse costs orders. Having such a

99 Mitchell (n 91).

100 CPR 3.9 deals with applications for relief from sanctions.

101 Denton (n 46) [43] (Lord Dyson MR and Vos LJ). 
provision has the benefit of providing the courts with a general power to take into account any relevant steps the parties could have taken (but failed to take) during the litigation process that could have saved the parties and the courts cost and time. This provision would further justify the courts making POs in circumstances where the successful party could have engaged in ADR but failure to do so has meant that both parties have had to incur further costs in the matter continuing to be pursued through the court process. The following approach could be adopted from the Singaporean civil justice system.

Although ADR is not mandatory in Singapore, the Subordinate Courts have implemented a 'presumption of ADR' for civil matters. This expressly endorsed the early use of ADR. The effect of the presumption is that cases filed in the Subordinate Courts are automatically referred to the most appropriate mode of ADR unless any or all of the parties opt out of ADR. ${ }^{102}$ Although the parties may opt out, they risk being punished in costs at a later stage. Order 59 rule $5(1)$ (c) of the Rules of Court ${ }^{103}$ prescribes the types of orders that can be made:

The Court in exercising its discretion as to costs shall, to such extent, if any, as may be appropriate in the circumstances, take into account the parties' conduct in relation to any attempt at resolving the cause or matter by mediation or any other means of dispute resolution.

The courts have further extensive powers to penalise a party in costs for misconduct or neglect under Order 59 rule 7, which would include a party's failure to engage in ADR. Order 59 rule 7 states:

(1) Where it appears to the Court in any proceedings that anything has been done, or that any omission has been made, unreasonably or improperly by or on behalf of any party, the Court may order that the costs of that party in respect of the act or omission, as the case may be, shall not be allowed and that any costs occasioned by it to any other party shall be paid by him to that other party. 104

(2) Without prejudice to the generality of paragraph (1), the Court shall for the purpose of that paragraph have regard in particular to the following matters:

(a) the omission to do anything the doing of which would have been calculated to save costs. 105

The Singaporean system is interesting because its costs regime is better linked to its strong commitment to the parties' obligation to engage in ADR. The 'presumption of ADR' referral system acts as a form of quasi-compulsory mediation in that an automatic referral will be made but the parties still have the freedom to opt out, albeit at the risk of a costs order being made against them at a later stage. The Singaporean approach also goes further than the English approach in that it formally recognises the courts' role in serving society with a 'variety of processes for timely resolution of disputes'. This radically alters the traditional perception of the role of the courts from one in which courts are perceived as

102 Subordinate Courts Practice Direction Amendment No 2 of 2012. Relevant amendments were also made to the pre-action protocols for non-injury motor accident, medical negligence and personal injury claims to ensure that the schemes would be in alignment with the guidelines for a 'presumption of ADR'. The 2012 presumption of ADR was followed with the passing of the State Courts Practice Directions Amendment No 4 of 2014 <https://app.statecourts.gov.sg/Data/Files/file/cdr/PD $\% 20$ Amendment $\% 20$ No $\% 204 \%$ $20 \mathrm{of} \% 202014$.pdf $>$. These amendments expand the presumption to apply to cases that are called for pre-trial conferences four months after the writ is filed. Amendment No 4 took effect in August 2014.

103 Supreme Court of Judicature Act (chapter 322, s 80), Rules of Court, R5 GN No S 71/1996, revised edn 2014 (21 March 2014).

104 Emphasis added.

105 Emphasis added. 
principally concerned with dealing with litigation to one which views their role in a more dynamic way, as a service provider of other methods of dispute resolution. By contrast, Zuckerman has contended that the function of the civil court is to deliver a public service for the enforcement of rights rather than merely a dispute resolution process. ${ }^{106}$ Unlike the Singaporean system, which speaks of the courts providing a 'variety' of processes for the resolution of disputes, Zuckerman warns of the danger of regarding courts as one form of dispute resolution when he states: 'to regard court adjudication as simply one of many forms of private dispute resolution is to debase its constitutional function in a system governed by the rule of law ... Court adjudication is the process which provides citizens with remedies for wrongs that they have suffered.' ${ }^{107}$

Order 59 rule 5(1)(c) reflects Singapore's strong ADR commitment because it makes specific reference to mediation and ADR generally. The equivalent provision under the English costs regime, CPR 44.4 (3)(ii), rather than expressly mentioning a particular type of ADR procedure, simply refers to the parties' conduct in 'trying to resolve the dispute'.

Despite these differences, the Singaporean cost regime does bear some similarities to the English system. Order 59 rule 7(1) includes what appears to be POs, which oblige a party found to have caused another party to incur unnecessary costs to reimburse those costs. But Order 59 rule 7(2) goes further than the English system. Order 59 rule 7(2) provides guidance on Order 59 rule 7(1) by setting out factors the court can take into account when exercising its discretion and these include the failure of a party to do anything that would have saved costs. As discussed, ADR procedures are generally perceived as cost-saving mechanisms when compared with the court process and therefore it would follow from the wording of Order 59 rule 7(2) that a failure to engage in ADR would be considered as saving costs. An equivalent provision to Order 59 rule 7(2) is missing under the CPR which, if included, would make clear to all who engage in the civil justice system that the courts will consider potential cost-saving steps, such as ADR, that could have saved costs when the court considers making costs orders. Indeed, a provision which incorporates the principle of causation, similar to Order 59 rule 7(1), thereby links the failure of one party to engage with ADR with the financial loss suffered to the other party (including the adverse impact this may have on finite court resources). Some support for this proposition can be taken from the Court of Appeal decision in Arkin $v$ Borchard. ${ }^{108}$ That case concerned an impecunious claimant and the issue was whether the successful defendants could recover their costs from a third-party funder of the claimant. Confirming that the defendants could pursue the third party, Lord Phillips was of the view that causation was a significant factor in justifying a costs order against a non-party. His Lordship explained:

Causation is also often a vital factor in leading a court to make a costs order against a non-party. If the non-party is wholly or partly responsible for the fact that litigation has taken place, justice may demand that he indemnify the successful party for the costs that he has incurred. ${ }^{109}$

It is argued that a direct link between a party's failure to engage with ADR and the financial loss suffered to the other party (which may be the unsuccessful party) will reinforce and clarify the court's wide-ranging costs powers.

This article has revealed a paradoxical situation which currently exists within ADR jurisprudence: the discrepancy between strong and enthusiastic judicial endorsement of

106 Adrian Zuckerman, Civil Procedure Principles of Practice (Sweet \& Maxwell 2013).

107 Ibid 1.6.

108 Arkin v Borchard [2005] EWCA Civ 655.

109 Ibid [24] (Lord Phillips MR). 
ADR but a failure on behalf of the senior judiciary to reflect this by making appropriate adverse costs orders, especially POs. There is a need for a change in judicial attitudes towards compulsory mediation, more effective utilisation of the overriding objective and greater use by the courts of their costs powers when dealing with ADR within the civil justice system. 